\title{
Origin of $\mathrm{Fe}-\mathrm{Ni}-\mathrm{Cu}$ sulfides in the 1.77Ga mafic dyke from Satkosia area, Singhbhum Craton (eastern India)
}

\author{
ARNAB DEY AND SISIR K. MONDAL \\ Jadavpur University \\ Presenting Author: arnabdey611@gmail.com
}

Numerous mafic dykes of $\sim 2.8-1.7 \mathrm{Ga}$ age intruded the Archean granitic crust $(\sim 3.5-3.3 \mathrm{Ga})$ in the Singhbhum Craton. The dykes are oriented in four major directions e.g., NE-SW to NNE-SSW, NW-SE to WNW-ESE, N-S, and E-W. This study is based on the $\sim 1.77 \mathrm{Ga}$ WNW-ESE trending Pipilia dykes that have been sampled from the Satkosia area in Orissa-state. The dyke samples from Satkosia have augite ( $34-51$ modal $\%$; Mg\# $\approx 65.7-82.6 ; \mathrm{En}_{37-48} \mathrm{Fs}_{11-17} \mathrm{Wo}_{36-41}$ ), clinoenstatite ( 2 modal\%; $\left.\mathrm{Mg} \# \approx 68.5-78 ; \mathrm{En}_{63-70} \mathrm{Fs}_{20-29} \mathrm{Wo}_{4-5}\right)$, and plagioclase $(\sim 35-40$ modal $\%$; $\left.\mathrm{An}_{11-39} \mathrm{Ab}_{44-82} \mathrm{Or}_{1-7}\right)$, and show cumulate texture at the central part and intergranular texture at the marginal part. The doleritic rocks are also characterized by the occurrence of granophyric texture ( $\sim 1-9$ modal $\%)$. Accessory minerals are FeTi-oxides $(\sim 5$ modal $\%)$, and are titanomagnetite $(\mathrm{FeO} \approx 34.38$ $39.50 \mathrm{wt} \%, \mathrm{Fe}_{2} \mathrm{O}_{3} \approx 48.26-56.21 \mathrm{wt} \%, \mathrm{TiO}_{2} \approx 5.05-9.60 \mathrm{wt} \%$ ), ilmenite ( $\mathrm{FeO} \approx 40.75-43.79 \mathrm{wt} \%, \mathrm{Fe}_{2} \mathrm{O}_{3} \approx 3.54-10.03 \mathrm{wt} \%, \mathrm{TiO}_{2}$ $\approx 47.82-50.87 \mathrm{wt} \%)$ and sulfides $(<1$ modal\%). Sulfide minerals are disseminated throughout the dyke at Satkosia, and occur along the interstices of silicate and oxide minerals. Sulfide mineral assemblage contains pyrite \pm chalcopyrite \pm vaesite. Pyrite has $\mathrm{Ni} \approx 0.02-1.95 \mathrm{wt} \%$ and $\mathrm{Co} \approx 0.01-5.70 \mathrm{wt} \%$, and shows weak negative correlation with Fe. Coexisting chalcopyrite has $\mathrm{Ni} \approx 0.07-0.30 \mathrm{wt} \%$ and $\mathrm{Co} \approx 0.02-0.08 \mathrm{wt} \%$. Vaesite contains $\mathrm{Ni} \approx 26.40-47.88 \mathrm{wt} \%$, Co $\approx 2.42-10.44 \mathrm{wt} \%$, $\mathrm{Fe} \approx 5.54-26.55 \mathrm{wt} \%$, and $\mathrm{S} \approx 41.58-46.67 \mathrm{wt} \%$, and plots below the actual field of vaesite in the Fe-Ni-S ternary diagram. Twopyroxene thermometry yield a temperature range of $1065-978^{\circ} \mathrm{C}$ and coexisting titanomagnetite-ilmenite reveals equilibration temperature of $731^{\circ} \mathrm{C}-573^{\circ} \mathrm{C}$ with corresponding $f \mathrm{O}_{2}$ at $\mathrm{NNO}+0.3$ to FMQ-1.03. The primary magmatic sulfide liquid segregated from the tholeiitic basaltic magma due to decrease in $\mathrm{FeO}$ activity after the crystallization of magnetite. The immiscible sulfide liquid was relatively S-rich and evolved along the S-rich portion of the Fe-Ni-S system and initially crystallized monosulfide solid solution from which pyrite and vaesite were exsolved during subsolidus cooling below $700{ }^{\circ} \mathrm{C}$. Globally $\sim 1.77-1.79 \mathrm{Ga}$ dykes and related LIPs are known to host $\mathrm{Ni}-\mathrm{Cu}$ sulfide deposits, and the first reported occurrence of sulfides in the $\sim 1.77 \mathrm{Ga}$ Singhbhum dyke increases the exploration potentiality of the mafic rocks of this age in the craton. 